\title{
Relation between airborne arsenic trioxide and urinary excretion of inorganic arsenic and its methylated metabolites
}

\author{
J A Offergelt, H Roels, J P Buchet, M Boeckx, R Lauwerys
}

\begin{abstract}
The relation between exposure to $\mathrm{As}_{2} \mathrm{O}_{3}$ fumes and dust, and the urinary excretion of inorganic arsenic metabolites (monomethylarsonic acid, dimethylarsinic acid, unchanged inorganic arsenic) has been studied in 18 workers from a sulphuric acid producing plant. The concentration of arsenic in the breathing zone of each worker was measured during five consecutive days and urine samples were obtained after one shift and before the next. The collection efficiency of the air sampling system exceeded $95 \%$. The time weighted average exposure (TWA) concentrations of $\mathrm{As}_{2} \mathrm{O}_{3}$ ranged from 6 to $502 \mu \mathrm{g} \mathrm{As} / \mathrm{m}^{3}$ and were log normally distributed. Although exposure probably occurred by ingestion as well as inhalation, statistically significant correlations ( $\log$ scales) were found between airborne TWA of $\mathrm{As}_{2} \mathrm{O}_{3}$ and the inorganic arsenic metabolites in urine collected immediately after the shift, or just before the next shift. For a TWA of $50 \mu \mathrm{g} \mathrm{As} / \mathrm{m}^{3}$, the mean concentration of the sum of the three inorganic arsenic metabolites in a postshift urine sample amounted to about $55 \mu \mathrm{g}$ arsenic/g creatinine (95\% confidence interval (95\% CI) 47-62). Higher estimates of urinary arsenic reported by other authors are probably due either to the influence of dietary organoarsenicals when total arsenic is measured in urine or to a low retention efficiency of the air sampling system for $\mathrm{As}_{2} \mathrm{O}_{3}$ in the vapour phase.
\end{abstract}

After their absorption, inorganic trivalent arsenic compounds are mainly excreted in the urine. ${ }^{12}$ Assessment of occupational exposure to inorganic arsenic has usually been carried out by measuring the

Industrial Toxicology and Occupational Medicine Unit, School of Medicine, Catholic University of Louvain, B-1200 Brussels, Belgium

J A Offergelt, H Roels, J P Buchet, M Boeckx, R Lauwerys concentration of total arsenic in urine collected at the end of the shift or at the beginning of the next shift. This measurement cannot distinguish between occupational exposure to inorganic arsenic and absorption of organoarsenicals (mainly - arsenobetaine) of negligible toxicity present at very high concentration in various marine organisms. ${ }^{3}$ Variable background concentrations of total arsenic may be found in urine, depending on the dietary habits of the workers.

Several metabolic studies performed during the last 10 years on in vitro systems,${ }^{4-7}$ animals, ${ }^{8}$ healthy human volunteers, ${ }^{12}$ patients suffering from liver diseases, ${ }^{9}$ and observations on subjects acutely intoxicated with $\mathrm{As}_{2} \mathrm{O}_{3}{ }^{10}$ have greatly clarified the metabolic handling of inorganic trivalent arsenic in vivo (fig 1) and permitted the development of a more specific biological monitoring method than the determination of total arsenic in urine.

It has now been shown that when exposure has been to inorganic arsenic, the only significant arsenic species excreted in urine are monomethylarsonic acid (MMA), dimethylarsinic acid (DMA) and inorganic arsenic (Asi). The determination of the three arsenic species in urine, therefore, is the method of choice for the biological monitoring of workers exposed to inorganic arsenic as this measurement is not influenced by the presence of organoarsenicals of dietary origin. In non-occupationally exposed subjects, the sum of the concentration of the three metabolites in urine is usually less than $10 \mu \mathrm{g} / \mathrm{g}$ creatinine. ${ }^{3}$

So far, only two studies have attempted to assess the relation between the urinary excretion of inorganic arsenic metabolites (Asi + MMA + DMA) and exposure to $\mathrm{As}_{2} \mathrm{O}_{3}$ and their conclusions are different. In 82 copper smelter workers, Smith et al ${ }^{11}$ found significant relations between exposure to $\mathrm{As}_{2} \mathrm{O}_{3}$ and the concentration of all urinary arsenic species in first void urine. The authors have only reported the regression equation between airborne arsenic and DMA in urine, but as DMA represented $65 \%$ of the arsenic metabolites, and the proportion of arsenic species was relatively constant and independent of exposure, it can be estimated that an exposure to $50 \mu \mathrm{g}$ arsenic $/ \mathrm{m}^{3}$ corresponds to a mean urinary 


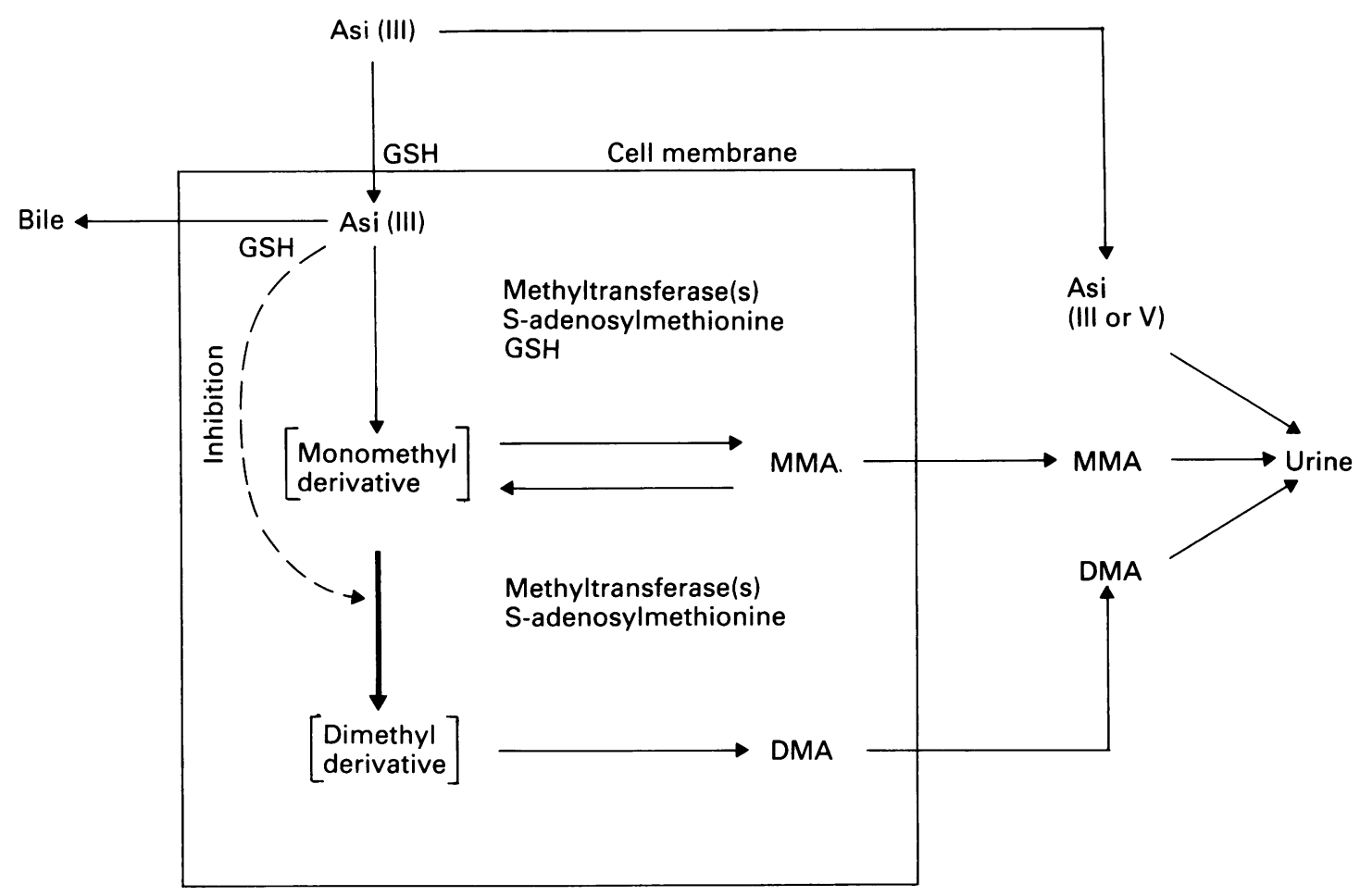

Figure 1 Biotransformation of inorganic trivalent arsenic (Asi (iii)).

level of $62 \mu \mathrm{g} / 1$ (specific gravity: 1.018) for the sum of the three species (Asi + MMA + DMA). The authors, however, noted that the relation between total airborne arsenic and arsenic excretion was probably modified by the use of chemical cartridge respirators by the smelter workers to filter their breathing air. In 13 smelter workers exposed to $\mathrm{As}_{2} \mathrm{O}_{3}$ and elemental arsenic, Vather et al ${ }^{12}$ found an excellent linear regression $(r=0.92)$ between the mean airborne concentration of arsenic and the mean concentration of total inorganic arsenic metabolites (Asi + MMA + DMA) in the first void urine (mean of two or three days for each person) but these authors estimated that an exposure to $50 \mu \mathrm{g} \mathrm{As} / \mathrm{m}^{3}$ would lead to a mean urinary excretion of inorganic arsenic metabolites of $190 \mu \mathrm{g} / \mathrm{l}$ (specific gravity: 1.019). In four other workers, the amount of arsenic excreted in urine was higher than expected on the basis of airborne concentration. The authors have suggested that exposure to arsenic by direct ingestion via contaminated hands, cigarettes, or snuff was the likely explanation. Because the retention efficiency of the air sampling system was not assessed, however, an underestimation of the amount of arsenic inhaled cannot formally be excluded. The authors, furthermore, did not attempt to monitor the excretion of each metabolite specifically. The present investigation was undertaken to further clarify the relation between exposure to $\mathrm{As}_{2} \mathrm{O}_{3}$ fumes and dust and the urinary excretion of Asi, MMA, and DMA.

\section{Material and methods \\ STUDY POPULATION}

The study was conducted in a chemical factory producing sulphuric acid by a process involving the roasting of pyrite containing $0.45 \%$ of arsenic; $\mathrm{As}_{2} \mathrm{O}_{3}$ dust and fumes were released mainly during the early steps of the production process.

Twenty two male workers clinically in good health (mean age 38) participated in the study; four of them (controls) were occupied in a section of the plant with no occupational exposure to arsenic. None of the workers used a respiratory protective device.

During five consecutive days, after two days already at work, the 18 exposed workers were equipped during the whole shift with a personal sampler for the collection of $\mathrm{As}_{2} \mathrm{O}_{3}$ fumes and dust (see later) and they provided spot urine samples immediately after the shift $(2.00 \mathrm{pm})$ and just before the start of the next shift the following day $(6.00 \mathrm{am})$. The postshift urine samples were collected after the workers had removed their workclothes and washed 
their hands. On the next two days off work and the day of return to work a sample of urine was also collected at $8.00 \mathrm{am}$. For the control workers, assessment of environmental exposure to arsenic with a personal sampler, and the urine collection after the shift and before the next shift, were only carried out on one day.

\section{AIR SAMPLING}

Personal air sampling was performed with a battery operated pump (type AFC123 Casella Ltd, London) connected to a filter holder attached to the shoulder of the subject. Air was aspirated at a flow rate of $1.5 \mathrm{l} / \mathrm{min}$ through a cellulose acetate filter (Millipore AAW, P03700, porosity $0.8 \mu \mathrm{m}$, diameter $25 \mathrm{~mm}$ ). Twelve hours before use, $0.3 \mathrm{ml}$ of a glycerol solution (containing $5 \mathrm{ml}$ glycerol and $9.5 \mathrm{~g} \mathrm{Na}_{2} \mathrm{CO}_{3}$ made up to $100 \mathrm{ml}$ with $\mathrm{H}_{2} \mathrm{O}$ ) had been uniformly applied. ${ }^{13}$ The excellent collection efficiency of the treated filter for $\mathrm{As}_{2} \mathrm{O}_{3}$ dust and fumes was confirmed in a separate field experiment. For this purpose, an impinger containing $150 \mathrm{ml} 0 \cdot 1 \mathrm{~N} \mathrm{NaOH}$ as scrubbing solution was placed between the pump and the filter. The system was operated as a static sampler and was placed for about four hours at $1.5 \mathrm{~m}$ above ground at four workplaces representative of the main working areas. Arsenic in air was found to be $19-164 \mu \mathrm{g} / \mathrm{m}^{3}$.
The total amount of arsenic collected on the filter and in the scrubbing solution ranged from 6.6 to $50.6 \mu \mathrm{g}$. The fraction retained on the filter always exceeded 95\% of the total. Personal sampling, therefore, was carried out with the treated filter only.

\section{ANALYSES}

Air

The filter was placed in a beaker, $5 \mathrm{ml} \mathrm{HNO}_{3}(65 \%)$ and $1 \mathrm{ml}$ saturated aqueous $\mathrm{Mg}\left(\mathrm{NO}_{3}\right)_{2}$ were added, and the contents, heated to $95^{\circ} \mathrm{C}$ for one to two hours until dissolution of the filter occurred. The residue was redispersed in $20 \mathrm{ml}$ of demineralised water and $10 \mathrm{ml}$ transferred into a crucible to which $1 \mathrm{~g} \mathrm{MgO}$ and $1 \mathrm{ml}$ saturated aqueous $\mathrm{Mg}\left(\mathrm{NO}_{3}\right)_{2}$ were added. After evaporation on a hot plate $\left(95^{\circ} \mathrm{C}\right)$ the crucible was placed in a muffle furnace and maintained at $600^{\circ} \mathrm{C}$ for 1.5 hours. After cooling, $20 \mathrm{ml} 12.5 \mathrm{~N} \mathrm{HCl}$ was mixed with the residue. The crucible was placed on a hot plate to allow complete dissolution of the material and the final volume adjusted to $25 \mathrm{ml}$.

The arsenic content of the sample was measured with the same technique as that used for urine (arsine generation (Perkin Elmer MHS-20) followed by atomic absorption spectrometry (Varian AA 1275)).

This technique was also used for the determination of arsenic collected in the $0 \cdot 1 \mathrm{~N} \mathrm{NaOH}$ scrubbing

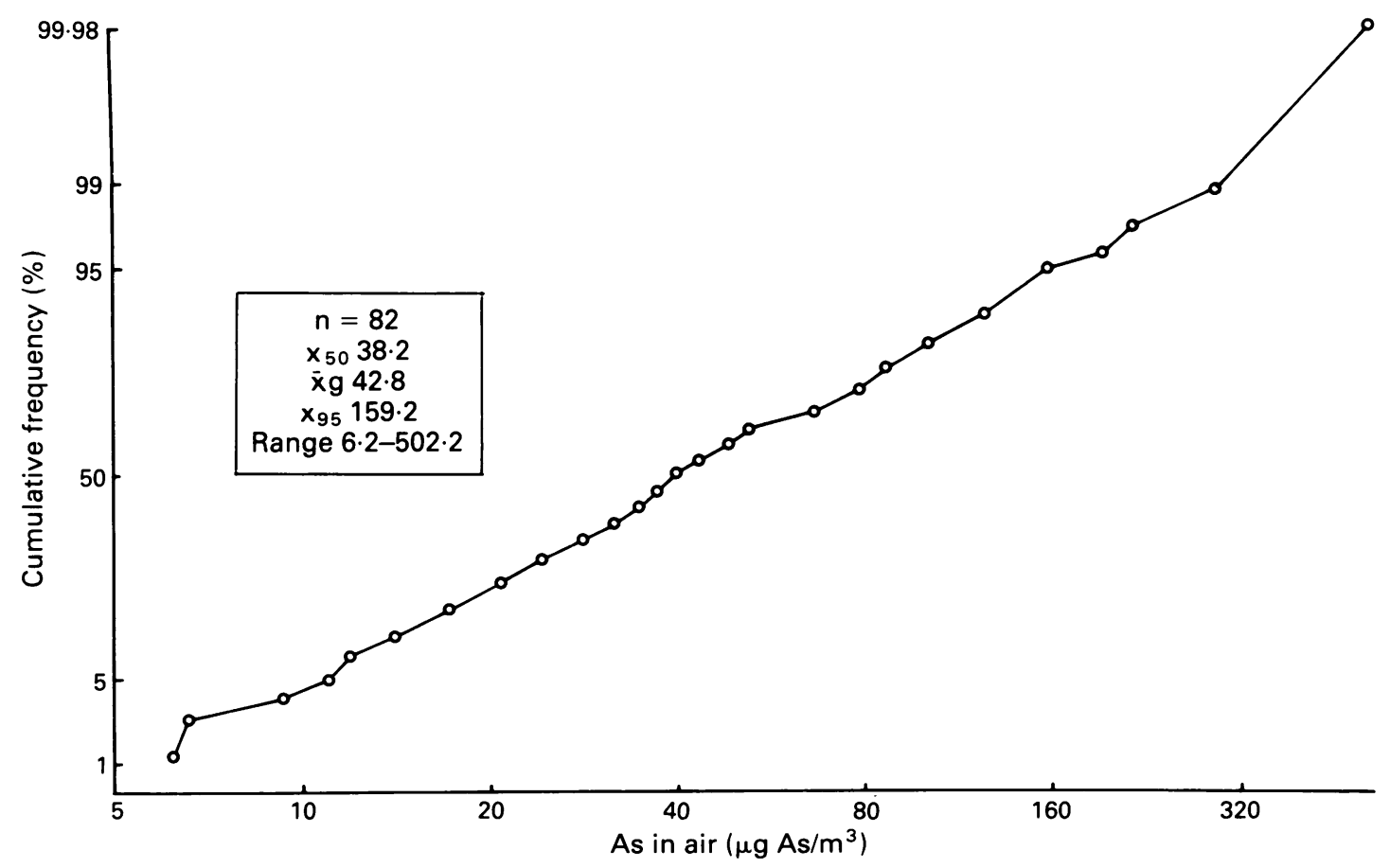

Figure 2 Cumulative frequency distribution of arsenic concentration in air $\left(\mathrm{As}_{2} \mathrm{O}_{3}\right)$ measured by personal sampler. 
Table 1 Follow up of daily concentrations of $\mathrm{As}_{2} \mathrm{O}_{3}$ in air measured by personal sampler and of arsenic metabolites in urine collected immediately after the shift and before the next shift

\begin{tabular}{|c|c|c|c|c|c|c|c|c|c|c|}
\hline \multirow[b]{3}{*}{ Day } & \multirow[b]{3}{*}{$\begin{array}{l}\text { No of } \\
\text { workers }\end{array}$} & \multirow[b]{3}{*}{$\begin{array}{l}\text { Arsenic in } \\
\text { air }\left(\mu g / m^{3}\right)\end{array}$} & \multicolumn{8}{|c|}{ Arsenic metabolites in urine ( $\mu \mathrm{g} / \mathrm{g}$ creatinine) } \\
\hline & & & \multicolumn{2}{|l|}{$\overline{A s i}$} & \multicolumn{2}{|l|}{$M M A$} & \multicolumn{2}{|l|}{$D M A$} & \multicolumn{2}{|c|}{$A s i+M M A+D M A$} \\
\hline & & & $\begin{array}{l}\text { After } \\
\text { shift }\end{array}$ & $\begin{array}{l}\text { Before } \\
\text { next shift }\end{array}$ & $\begin{array}{l}\text { After } \\
\text { shift }\end{array}$ & $\begin{array}{l}\text { Before } \\
\text { next shift }\end{array}$ & $\begin{array}{l}\text { After } \\
\text { shift }\end{array}$ & $\begin{array}{l}\text { Before } \\
\text { next shift }\end{array}$ & $\begin{array}{l}\text { After } \\
\text { shift }\end{array}$ & $\begin{array}{l}\text { Before } \\
\text { next shift }\end{array}$ \\
\hline \multicolumn{11}{|c|}{ Exposed workers: } \\
\hline 1 & 15 & $\begin{array}{l}41 \cdot 5 \\
(14 \cdot 6-292 \cdot 7)\end{array}$ & $\begin{array}{l}12 \cdot 8 \\
(4 \cdot 0-35 \cdot 6)\end{array}$ & $\begin{array}{l}6 \cdot 8 \\
(2 \cdot 0-21 \cdot 1)\end{array}$ & $\begin{array}{l}8 \cdot 1 \\
(1 \cdot 2-40 \cdot 7)\end{array}$ & $\begin{array}{l}9 \cdot 3 \\
(2 \cdot 2-42 \cdot 4)\end{array}$ & $\begin{array}{l}26 \cdot 5 \\
(7 \cdot 9-100 \cdot 2)\end{array}$ & $\begin{array}{l}26 \cdot 1 \\
(8 \cdot 0-104 \cdot 6)\end{array}$ & $\begin{array}{l}49 \cdot 5 \\
(15 \cdot 3-157 \cdot 5)\end{array}$ & $\begin{array}{l}44 \cdot 5 \\
(14 \cdot 7-168 \cdot 1)\end{array}$ \\
\hline 2 & 16 & $\begin{array}{l}37 \cdot 1 \\
(11 \cdot 0-156 \cdot 8)\end{array}$ & $\begin{array}{l}11.9 \\
(5 \cdot 1-26 \cdot 6)\end{array}$ & $\begin{array}{l}5.4 \\
(1.9-11.9)\end{array}$ & $\begin{array}{l}7.1 \\
(2 \cdot 0-11 \cdot 9)\end{array}$ & $\begin{array}{l}7 \cdot 1 \\
(1 \cdot 6-14 \cdot 7)\end{array}$ & $\begin{array}{l}24 \cdot 8 \\
(6 \cdot 0-67 \cdot 8)\end{array}$ & $\begin{array}{l}26 \cdot 4 \\
(5 \cdot 2-74 \cdot 8)\end{array}$ & $\begin{array}{l}45 \cdot 6 \\
(17 \cdot 5-106 \cdot 3)\end{array}$ & $\begin{array}{l}40 \cdot 0 \\
(10 \cdot 6-91 \cdot 1)\end{array}$ \\
\hline 3 & 16 & $\begin{array}{l}47 \cdot 3 \\
(11 \cdot 2-150 \cdot 4)\end{array}$ & $\begin{array}{l}10 \cdot 9 \\
(4 \cdot 4-37 \cdot 0)\end{array}$ & $\begin{array}{l}6 \cdot 2 \\
(1 \cdot 9-22 \cdot 1)\end{array}$ & $\begin{array}{l}7 \cdot 3 \\
(1 \cdot 8-25 \cdot 4)\end{array}$ & $\begin{array}{l}7 \cdot 7 \\
(2 \cdot 2-32 \cdot 6)\end{array}$ & $\begin{array}{l}27 \cdot 6 \\
(8 \cdot 2-102 \cdot 9)\end{array}$ & $\begin{array}{l}30 \cdot 2 \\
(7 \cdot 1-103 \cdot 4)\end{array}$ & $\begin{array}{l}47 \cdot 5 \\
(18 \cdot 3-149 \cdot 4)\end{array}$ & $\begin{array}{l}45 \cdot 9 \\
(17 \cdot 2-155 \cdot 2)\end{array}$ \\
\hline 4 & 17 & $\begin{array}{l}37 \cdot 3 \\
(6 \cdot 5-159 \cdot 2)\end{array}$ & $\begin{array}{l}12 \cdot 3 \\
(3 \cdot 7-55 \cdot 4)\end{array}$ & $\begin{array}{l}6 \cdot 0 \\
(1 \cdot 6-23.9)\end{array}$ & $\begin{array}{l}7 \cdot 3 \\
(1 \cdot 5-30 \cdot 4)\end{array}$ & $\begin{array}{l}8 \cdot 2 \\
(1 \cdot 8-38 \cdot 6)\end{array}$ & $\begin{array}{l}32 \cdot 3 \\
(9 \cdot 4-105 \cdot 4)\end{array}$ & $\begin{array}{l}34 \cdot 6 \\
(6 \cdot 2-127 \cdot 6)\end{array}$ & $\begin{array}{l}54 \cdot 6 \\
(18 \cdot 2-173 \cdot 7)\end{array}$ & $\begin{array}{l}50 \cdot 5 \\
(12 \cdot 7-190 \cdot 2)\end{array}$ \\
\hline 5 & 18 & $\begin{array}{l}52 \cdot 2 \\
(6 \cdot 2-502 \cdot 2)\end{array}$ & $\begin{array}{l}14 \cdot 7 \\
(4 \cdot 5-131 \cdot 0)\end{array}$ & $\begin{array}{l}6 \cdot 8 \\
(2 \cdot 3-38 \cdot 5)\end{array}$ & $\begin{array}{l}7 \cdot 5 \\
(2 \cdot 1-40 \cdot 9)\end{array}$ & $\begin{array}{l}10 \cdot 8 \\
(3 \cdot 7-56 \cdot 1)\end{array}$ & $\begin{array}{l}31.9 \\
(10.7-96.4)\end{array}$ & $\begin{array}{l}36 \cdot 3 \\
(11 \cdot 4-131 \cdot 8)\end{array}$ & $\begin{array}{l}56 \cdot 9 \\
(23 \cdot 0-268 \cdot 3)\end{array}$ & $\begin{array}{l}55 \cdot 5 \\
(21 \cdot 7-226 \cdot 4)\end{array}$ \\
\hline 6 & 18 & - & - & $3 \cdot 3$ & - & $6 \cdot 1$ & - & $22 \cdot 8$ & - & $35 \cdot 7$ \\
\hline & & 一 & - & $(1 \cdot 1-40 \cdot 4)$ & - & $(1 \cdot 4-54 \cdot 3)$ & - & $(1 \cdot 0-137 \cdot 2)$ & - & $(9 \cdot 9-231 \cdot 8)$ \\
\hline 7 & 18 & 二 & 二 & $\begin{array}{l}2 \cdot 6 \\
(0 \cdot 9-8 \cdot 9)\end{array}$ & 二 & $\begin{array}{l}4 \cdot 6 \\
(1 \cdot 2-14 \cdot 6)\end{array}$ & 二 & $\begin{array}{l}24 \cdot 1 \\
(4 \cdot 7-82 \cdot 6)\end{array}$ & 二 & $\begin{array}{l}33 \cdot 2 \\
(10 \cdot 9-94 \cdot 4)\end{array}$ \\
\hline \multicolumn{11}{|c|}{ Control workers: } \\
\hline
\end{tabular}

Results are expressed as geometric mean and range (range only for control workers).

solution. It was checked that known amounts of $\mathrm{As}_{2} \mathrm{O}_{3}$ directly deposited on the filters were completely recovered.

Urine

The contents of Asi, MMA, and DMA in urine were determined as described previously. ${ }^{1}$ Urinary creatinine was measured according to Jaffe's picrate method. ${ }^{14}$ During the study, our laboratory participated in the external quality control programme for the analysis of arsenic (Asi + MMA + DMA) in urine organised by the Centre de Toxicologie du Quebec, Laval University, Quebec, Canada. The results exceeded the target values by a mean of $6.2 \%$ (standard deviation (SD) 4.9\%) $(\mathrm{n}=18)$.

\section{STATISTICAL ANALYSIS}

The measurements of arsenic in air and those of the inorganic arsenic metabolites in urine are all log normally distributed and are presented as geometric means. Pearson correlation coefficients $(r)$ and regression equations were calculated on log transformed data to assess the association between airborne arsenic concentration and arsenic metabolites in urine; SAS procedures were used..$^{15}$

\section{Results}

Urine samples with creatinine concentrations below $0.3 \mathrm{~g} / 1$ or above $3 \mathrm{~g} / 1$ were not taken into account for the data analysis. Hence for the 18 exposed workers the final database included results of 82 personal air samples and the corresponding post and preshift urine samples.
Figure 2 presents the results of arsenic concentrations in air measured with personal samplers. They were $\log$ normally distributed and ranged from 6 to
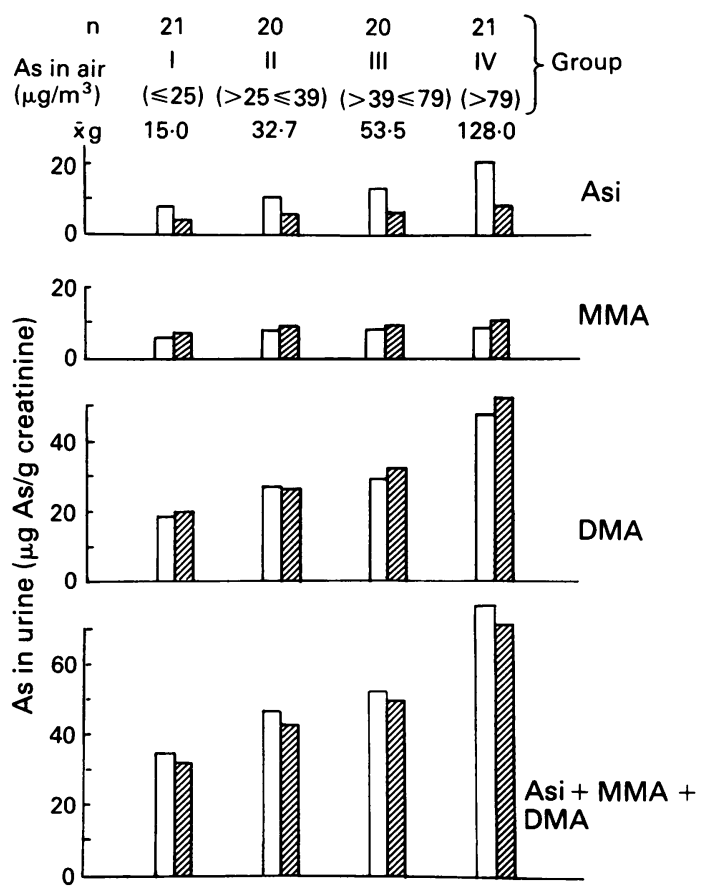

Figure 3 Geometric mean concentrations of arsenic metabolites in urine collected after and before the shift corresponding to each quartile of the cumulative distribution of arsenic concentration in air (after shift open columns; before next shift shaded columns). 


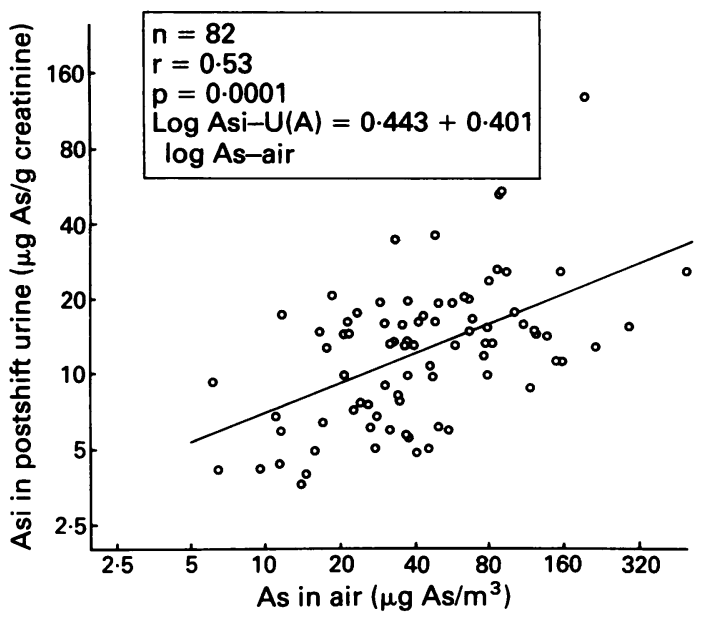

Figure 4 Correlation between inorganic arsenic concentration in urine after shift $(A s i-u(A))$ and the airborne concentration of arsenic.

$502 \mu \mathrm{g}$ arsenic $/ \mathrm{m}^{3}$. For the four control workers, the breathing zone air concentration of arsenic ranged from 0.1 to $0.3 \mu \mathrm{g}$ arsenic $/ \mathrm{m}^{3}$. The concentrations of arsenic metabolites in urine were also log normally distributed. Table 1 gives the geometric mean of the daily concentrations of arsenic in air and those of inorganic arsenic metabolites (Asi, MMA, DMA) in urine after and before each shift and during the two days off work. The values found in the control workers are also indicated.

The results of the airborne arsenic concentrations were divided into four groups corresponding to the quartiles of the cumulative frequency distribution, and the corresponding geometric mean values of the inorganic arsenic metabolites in urine were calculated (fig 3). These were significantly correlated with the mean airborne arsenic concentrations; the relative change was the lowest for MMA.

On an individual level, there was also a statistically significant correlation between the log of airborne arsenic and the $\log$ of arsenic metabolites in urine (table 2). Figures 4 and 5 illustrate the correlations between airborne arsenic and the concentration of inorganic arsenic and the sum of the inorganic arsenic metabolites in urine (Ast = Asi + MMA + DMA) collected after the shift respectively. For each worker, the geometric mean of the airborne arsenic concentration and the geometric mean of the three arsenic metabolite concentrations in urine during the work week were calculated (mean of four or five days). The correlation coefficients between the mean values $(n=18)$ were not higher than those between the individual concentrations (results not shown).

On the basis of the regression equations presented in table 2, we have estimated the inorganic arsenic metabolite concentrations in urine collected after and before the shift that correspond to various TWA concentrations of $\mathrm{As}_{2} \mathrm{O}_{3}$ dust and fumes (table 3).

\section{Discussion}

The airborne concentrations of arsenic at the control workplaces $\left(0.1-0.3 \mu \mathrm{g}\right.$ arsenic $\left./ \mathrm{m}^{3}\right)$ fall in the range measured in some cities. ${ }^{16}$ The concentrations of arsenic metabolites in urine of control workers also correspond to the usual background value in Belgium. In the sulphuric acid producing plant, the mean airborne concentrations of $\mathrm{As}_{2} \mathrm{O}_{3}$ and the urinary concentrations of the arsenic metabolites remained rather constant throughout the work week. Only for Asi was the mean concentration in urine collected after the shift significantly higher than that found the next morning. The proportion of Asi in urine fell from $25 \%$ of the total after the shift to $14 \%$ before the next shift. These results are in agreement with the results of our previous toxicokinetics studies in human subjects. ${ }^{12}$

The correlation coefficients between the concentration of each arsenic metabolite in urine collected after or before the shift and the airborne concentration of inorganic arsenic were statistically significant but were rather low; they varied between $0.4-0.5$ for Asi and DMA and were even lower (0.2-0.3) for MMA (table 2). This may be due to the fact that inhalation is not the only route of intake of arsenic but exposure by direct ingestion of dust is likely to occur as we have previously found in another factory. ${ }^{17}$ The interindividual variability in the relative importance of the biliary and urinary routes of arsenic excretion may also play a part.

The correlation coefficient between airborne con-

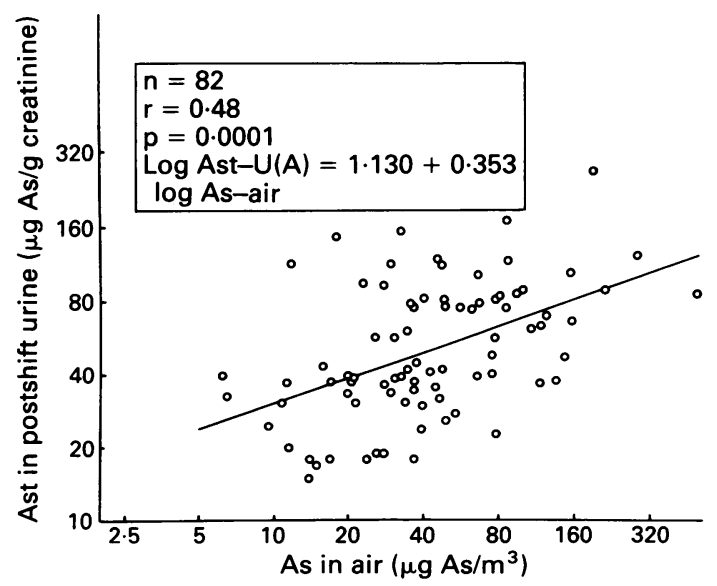

Figure 5 Correlation between inorganic arsenic metabolite (Ast $=A s i+M M A+D M A)$ concentration in urine after shift (Ast $-u(A))$ and the airborne concentration of arsenic. 
Table 2 Correlation coefficients and regression equations between the concentration of arsenic metabolites in urine collected immediately after the shift or before the next shift and the concentration of $\mathrm{As}_{2} \mathrm{O}_{3}$ in air measured with personal sampler

\begin{tabular}{|c|c|c|c|c|}
\hline Variables & No & rValue & p Value & Regression equations \\
\hline $\begin{array}{l}\log A s i(A)-\log A s-a i r \\
\log \text { Asi (B)-log As-air }\end{array}$ & $\begin{array}{l}82 \\
82\end{array}$ & $\begin{array}{l}0 \cdot 53 \\
0 \cdot 40\end{array}$ & $\begin{array}{l}0 \cdot 0001 \\
0 \cdot 0002\end{array}$ & 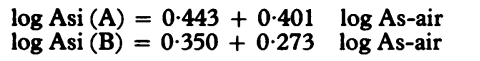 \\
\hline $\begin{array}{l}\log M M A(A)-\log A s-a i r \\
\log M M A(B)-\log A s-a i r\end{array}$ & $\begin{array}{l}82 \\
82\end{array}$ & $\begin{array}{l}0.24 \\
0.32\end{array}$ & $\begin{array}{l}0.0315 \\
0.0035\end{array}$ & $\begin{array}{l}\log \text { MMA (A) }=0.589+0.173 \quad \log \text { As-air } \\
\log \text { MMA (B) }=0.542+0.240 \quad \log \text { As-air }\end{array}$ \\
\hline $\begin{array}{l}\log \text { DMA (A)- } \log \text { As-air } \\
\log \text { DMA (B)- } \log \text { As-air }\end{array}$ & $\begin{array}{l}82 \\
82\end{array}$ & $\begin{array}{l}0.43 \\
0.45\end{array}$ & $\begin{array}{l}0.0001 \\
0.0001\end{array}$ & $\begin{array}{l}\log \text { DMA }(A)=0.843+0.376 \quad \log \text { As-air } \\
\log \text { DMA }(B)=0.812+0.414 \quad \log \text { As-air }\end{array}$ \\
\hline $\begin{array}{l}\log \text { Ast (A)-log As-air } \\
\log \text { Ast (B)-log As-air }\end{array}$ & $\begin{array}{l}82 \\
82\end{array}$ & $\begin{array}{l}0 \cdot 48 \\
0 \cdot 46\end{array}$ & $\begin{array}{l}0.0001 \\
0.0001\end{array}$ & $\begin{array}{l}\log \text { Ast }(A)=1.130+0.353 \quad \log \text { As-air } \\
\log \text { Ast }(B)=1.098+0.353 \quad \log \text { As-air }\end{array}$ \\
\hline
\end{tabular}

(A) = urine collected immediately after the shift; $(B)=$ urine collected before the beginning of the next shift;

Ast = Asi + MMA + DMA; As-air = arsenic in air.

centration of arsenic and concentration of MMA in urine is the lowest and this is in agreement with our knowledge on the metabolic handling of arsenic. We have shown that the first methylation reaction leading to MMA production is the rate limiting step in the metabolic process and after moderate exposure to inorganic arsenic, the MMA precursor rapidly undergoes a second methylation reaction leading to DMA (fig 1). ${ }^{7}$

When uptake of Asi exceeds a certain value (for example, after acute intoxication), the production of DMA can be transiently inhibited and this leads to an accumulation of MMA. ${ }^{5-7}$ Such a phenomenon was not found in the present study; the proportion of arsenic species was independent of exposure. It can therefore be concluded that occupational exposure of up to $300 \mu \mathrm{g}$ arsenic $/ \mathrm{m}^{3}$ does not inhibit the methylation of arsenic. Such interference may, however, transiently occur in the epithelial cells of the lung at the site of particle deposition and dissolution. This might have some impact on the local genotoxic effect of inorganic arsenic.
Despite the fact that exposure to $\mathrm{As}_{2} \mathrm{O}_{3}$ in the present workers is likely to occur not only by inhalation but also to a certain extent by ingestion, it is possible to provide some estimate of the Asi metabolite concentration in urine corresponding to different TWA exposure concentrations (table 3). A TWA exposure of $0.05 \mathrm{mg}$ arsenic $/ \mathrm{m}^{3}$ leads to a mean concentration of the sum of inorganic arsenic metabolites (Asi + MMA + DMA) in the postshift urine sample of $54 \mu \mathrm{g}$ arsenic/g creatinine $(95 \%$ confidence interval $(95 \% \mathrm{CI})=47-62)$ (table 3$)$. This estimate is much lower than that previously reported by Pinto et al ${ }^{18}$ and Vather et al..$^{12}$ The discrepancy cannot be due to a greater contribution of oral ingestion in the present study since this would lead to an overestimate of the urinary concentration. Pinto et al $^{18}$ have measured total arsenic in urine without speciation. Their results, therefore, may have been influenced by the dietary intake of organoarsenical compounds. Furthermore it is possible that the sampling system used by Pinto et al ${ }^{18}$ may have underestimated the airborne arsenic concentra-

Table 3 Estimates of concentrations of arsenic metabolites in urine collected after or before the shift corresponding to different TWA concentrations of $\mathrm{As}_{2} \mathrm{O}_{3}$ dust and fumes

\begin{tabular}{|c|c|c|c|c|c|c|c|c|}
\hline \multirow[b]{3}{*}{$\begin{array}{l}\text { As-air } \\
\left(\mu g / m^{3}\right)\end{array}$} & \multicolumn{8}{|c|}{ Arsenic metabolites in urine ( $\mu \mathrm{g} / \mathrm{g}$ creatinine) } \\
\hline & \multicolumn{2}{|l|}{$\overline{A s i}$} & \multicolumn{2}{|l|}{$M M A$} & \multicolumn{2}{|l|}{$D M A$} & \multicolumn{2}{|l|}{$A s t^{\star}$} \\
\hline & $\begin{array}{l}\text { After } \\
\text { shift }\end{array}$ & $\begin{array}{l}\text { Before } \\
\text { next shift }\end{array}$ & $\begin{array}{l}\text { After } \\
\text { shift }\end{array}$ & $\begin{array}{l}\text { Before } \\
\text { next shift }\end{array}$ & $\begin{array}{l}\text { After } \\
\text { shift }\end{array}$ & $\begin{array}{l}\text { Before } \\
\text { next shift }\end{array}$ & $\begin{array}{l}\text { After } \\
\text { shift }\end{array}$ & $\begin{array}{l}\text { Before } \\
\text { next shift }\end{array}$ \\
\hline $12 \cdot 5$ & 8 & 5 & 6 & 6 & 18 & 18 & 33 & 31 \\
\hline 25 & $\begin{array}{c}(0-10) \\
10 \\
(9-12)\end{array}$ & $\begin{array}{c}(4-6) \\
5 \\
(4-6)\end{array}$ & $\begin{array}{l}(5-8) \\
7 \\
(6-8)\end{array}$ & $\begin{array}{l}8-8) \\
(6-9)\end{array}$ & $\begin{array}{l}23 \\
(19-29)\end{array}$ & $\begin{array}{l}25 \\
(20-30)\end{array}$ & $\begin{array}{c}42 \\
(36-50)\end{array}$ & $\begin{array}{c}39 \\
(33-47)\end{array}$ \\
\hline 50 & $\begin{array}{l}13 \\
(12-15)\end{array}$ & $\begin{array}{c}7 \\
7 \\
(6-8)\end{array}$ & $\begin{array}{c}8 \\
8-9)\end{array}$ & $\begin{array}{l}9 \\
(8-10)\end{array}$ & $\begin{array}{l}30 \\
(26-36)\end{array}$ & $\begin{array}{l}33 \\
(27-39)\end{array}$ & $\begin{array}{c}54 \\
(47-62)\end{array}$ & $\begin{array}{c}50 \\
(43-58)\end{array}$ \\
\hline 100 & $\begin{array}{l}18 \\
(14-21)\end{array}$ & $\begin{array}{c}8 \\
(7-10)\end{array}$ & $\begin{array}{l}9 \\
(7-11)\end{array}$ & 11 & $\begin{array}{l}39 \\
(31-50)\end{array}$ & $\begin{array}{l}44 \\
(34-56)\end{array}$ & $\begin{array}{l}69 \\
(56-84)\end{array}$ & $\begin{array}{c}64 \\
(52-79)\end{array}$ \\
\hline 200 & $\begin{array}{l}23 \\
(17-31)\end{array}$ & $\begin{array}{l}10 \\
(7-13)\end{array}$ & $\begin{array}{l}10 \\
(7-13)\end{array}$ & 12 & $\begin{array}{l}51 \\
(36-73)\end{array}$ & $\begin{array}{l}58 \\
(40-84)\end{array}$ & $\begin{array}{l}88 \\
(65-117)\end{array}$ & $\begin{array}{l}81 \\
(60-111)\end{array}$ \\
\hline 400 & $\begin{array}{l}31 \\
(21-45)\end{array}$ & $\begin{array}{l}12 \\
(8-17)\end{array}$ & $\begin{array}{l}11 \\
(7-17)\end{array}$ & $\begin{array}{l}15 \\
(10-23)\end{array}$ & $\begin{array}{l}66 \\
(41-107)\end{array}$ & $\begin{array}{l}77 \\
(47-127)\end{array}$ & $\begin{array}{l}112 \\
(75-166)\end{array}$ & $\begin{array}{l}104 \\
(68-158)\end{array}$ \\
\hline
\end{tabular}

$\star$ Ast $=\mathrm{As}_{\mathrm{i}}+\mathrm{MMA}+\mathrm{DMA}$.

Results are expressed as geometric mean and $95 \% \mathrm{CI}$. 
tions at least if $\mathrm{As}_{2} \mathrm{O}_{3}$ vapour were released at some workplaces (see later).

The difference between our results and those of Vather et al $^{12}$ might be due to a greater contribution of oral intake of arsenic in the Swedish workers than in the present study. It is also possible that in the study by Vather $e t$ al, ${ }^{12}$ the airborne concentration of the arsenic dust and fumes has been underestimated. Collection was carried out with an unpretreated cellulose ester filter, and the collection efficiency of such filters for arsenic trioxide in vapour phase is only $42 \%$. $^{13}$ This hypothesis is supported by the fact that the regression line between airborne arsenic concentrations and metabolites in urine found by Vather et $a l^{12}$ has an intercept $(29 \mu \mathrm{g}$ arsenic/g creatinine) that is higher than the normal background concentration of urinary arsenic. Their results also indicate that the daily urinary excretion of arsenic corresponds on average to $74 \%$ of the total inhaled amount, which seems too high for an aerosol. Whatever the relation, the present study confirms that airborne concentration of Asi is not a satisfactory indicator of the total amount of arsenic absorbed on an individual basis. Because Asi can exhibit both local and systemic toxicity and as the bioavailability of various arsenic compounds may differ, the measurement of the arsenic concentration in the inhaled air, and that of the specific metabolites in urine, represent two complementary approaches to assess the risk of overexposure.

Requests for reprints to: $\mathbf{R}$ Lauwerys, Industrial Toxicology and Occupational Medicine Unit, School of Medicine, Catholic University of Louvain, B-1200 Brussels, Belgium.

1 Buchet JP, Lauwerys R, Roels H. Comparison of urinary excretion of arsenic metabolites after a single oral dose of sodium arsenite, monomethylarsonate and dimethylarsinate in man. Int Arch Occup Env Health 1981;48:71-9.

2 Buchet JP, Lauwerys R, Roels $H$. Urinary excretion of inorganic arsenic and its metabolites after repeated ingestion of sodium metaarsenite by volunteers. Int Arch Occup Environ Health 1981;48:111-8.

3 Buchet JP, Lauwerys R, Roels $H$. Comparison of several methods for the determination of arsenic compounds in water and in urine. Int Arch Occup Env Health 1980;46:11-29.

4 Fischer AB, Buchet JP, Lauwerys R. Arsenic uptake, cytotoxicity and detoxification in mammalian cells in culture. Arch Toxicol 1985;37:168-72.

5 Georis B, Cardenas A, Buchet JP, Lauwerys R. Inorganic arsenic methylation by rat tissue slices. Toxicology 1990; 63:73-84.

6 Buchet JP, Lauwerys R. Study of inorganic arsenic methylation by rat liver in vitro: relevance for interpretation of observations in man. Arch Toxicol 1985;57:125-9.

7 Buchet JP. Lauwerys R. Role of thiols in the in vitro methylation of inorganic arsenic by rat liver cytosol. Biochem Pharmacol 1988;37:3149-53.

8 Buchet JP, Lauwerys R. Study of factors influencing the in vivo methylation of inorganic arsenic in rats. Toxicol Appl Pharmacol 1987;91:65-74.

9 Buchet JP, Geubel A, Pauwels S, Mahieu P, Lauwerys R. The influence of liver disease on the methylation of arsenite in humans. Arch Toxicol 1984;55:151-4.

10 Mahieu P, Buchet JP, Roels H, Lauwerys R. The metabolism of arsenic in humans acutely intoxicated by $\mathrm{As}_{2} \mathrm{O}_{3}$. Its significance for the duration of BAL therapy. Clin Toxicol 1981;18:1067-75.

11 Smith TJ, Crecelius EA, Reading JC. Airborne arsenic exposure and excretion of methylated arsenic compounds. Environ Health Perspect 1977;19:89-93.

12 Vahter M, Friberg L, Rahnster B, Nygren A, Nolinder P. Airborne arsenic and urinary excretion of metabolites of inorganic arsenic among smelter workers. Int Arch Occup Environ Health 1986;57:79-91.

13 Costello RJ, Eller PM, Hull RD. Measurement of multiple inorganic arsenic species. Am Ind Hyg Assoc J 1983;44:21-8.

14 Henry RJ. Clinical chemistry: principles and technics. 3rd ed. New York: Harper and Row, 1965.

$15 S A S / S T A T$ guide for personal computers. Version 6. Cary, North Carolina: SAS Institute Inc, 1987.

16 World Health Organization. Air quality guidelines for Europe. Contional Publications. WHO, Regional Office for Europe, 1987. (European Series No. 23).

17 Roels H, Buchet JP, Truc J, Croquet F, Lauwerys R. The possible role of direct ingestion on the overall absorption of cadmium or arsenic in workers exposed to $\mathrm{CdO}$ or $\mathrm{As}_{2} \mathrm{O}_{3}$ dust. Am J Ind Med 1982;3:53-65.

18 Pinto SS, Varner MO, Nelson KW, Labbe AL, White LD. Arsenic trioxide absorption and excretion in industry. $J O c c u p$ Med 1976;18:677-80.

Accepted 23 September 1991 